https://doi.org/10.34101/actaagrar/73/1626

AgRÁRTUdOMÁNYi KÖZLEMÉNYEK, 2017/73.

\title{
Impact of chronic heat stress on digestibility of nutrients and performance of meat type ducks
}

\author{
Márta Horváth - László Babinszky \\ University of Debrecen Faculty of Agricultural and Food Sciences and Environmental Management, \\ Department of Animal Nutrition and Food Biotechnology, Debrecen \\ mhorvath@agr.unideb.hu
}

\section{SUMMARY}

The aim of the study is to determine the effect of vitamin and mineral supplement under permanently high environmental temperature $\left(30 \pm 1{ }^{\circ} \mathrm{C}\right)$ on the digestibility of nutrients, performance and furthermore the composition of duck meat in the growing period. A total of four hundred mixed sex 14 days old Cherry Valley type hybrid ducks were used for the study. Two experimental diets were formulated in the study (control and vitamin E, $C$ and zinc supplemented diet). Based on the results the following conclusions were drown: the antioxidant defence system plays an important role in the reduction of heat stress generated lipid peroxidation process. Feed additives which have direct or indirect antioxidant effects can reduce the negative effects of heat stress on the ducks performance and meat composition. Digestibility of nutrients (Dry Matter, Crude Protein, Crude Fat) was not affected by antioxidant supplementation under chronic heat stress (30 $\left.\pm{ }^{\circ} \mathrm{C}\right)$. The performance was affected significantly by Vitamin $C$ and $E$ and zinc supplementation under heat stress $(P<0.05)$. In the treated group the daily weight gain $(d W G)$ increased and the feed conversion ratio $(F C R)$ was improved significantly $(P<0.05)$. The energy and protein conversion was decreased also significantly $(P<0.05)$.

Keywords: heat stress, meat type duck, nutrient digestibility, performance, chemical composition of meat

\section{ÖSSZEFOGLALASS}

A közlemény célja, hogy bemutassa a vitamin- és ásványianyag-kiegészités hatását tartós höstressz ( $\left.30 \pm 1{ }^{\circ} \mathrm{C}\right)$ során a kacsa nevelési idöszakában a táplálóanyagok emészthetöségére, a termelési paraméterekre, valamint a hús kémiai összetételére. A kísérletbe összesen 400 vegyes ivarú elönevelt (14 napos) Cherry Valley hibrid kacsa került beállitásra. A kísérletben két kezelést alkalmaztunk (kontroll valamint C és E vitamin, továbbá cink kiegészités). A vizsgálataink alapján az alábbi fontosabb megállapitásokat tettük: az antioxidáns védelmi rendszernek kiemelkedö szerepe van a hősokk okozta lipidperoxidáció csökkentésében. Alkalmazhatók olyan takarmány kiegészitők, melyek direkt vagy indirekt antioxidáns tulajdonságúak, ezáltal csökkentik a höstressz káros hatásait a termelési paraméterekre és a hús összetételre. Höstressz során a táplálóanyagok emészthetőségét (szárazanyag, nyers fehérje, nyers zsír) nem befolyásolta az antioxidáns kiegészités. A termelési paraméterek szignifikánsan javultak $C$ és E vitamin, valamint cinkkiegészités hatására höstressz során $(P<0,05)$. A kezelt csoportban szignifikánsan javult a napi súlygyarapodás, a fajlagos takarmányértékesités, valamint a fajlagos energia- és fehérjeértékesités szignifikáns csökkenést mutatott $(P<0,05)$.

Kulcsszavak: höstressz, hús típusú kacsa, táplálóanyagok emészthetősége, termelési paraméterek, hús kémiai összetétele

\section{INTRODUCTION}

Nowadays the climate change has an effect both on everyday life, and also on the agriculture and food production. The higher environmental temperature may have more serious consequences: it changes the energy and nutrient metabolism of the animals, the antioxidant status could be impaired greatly, the resistance capacity decreases and the product quality is deteriorating on a final row (Babinszky et al. 2011). The negative effects of high environmental temperature could be reduced by genetic or keeping technology devices, but these methods are expensive and not in all cases are adequate. This is the reason why intensive researches are going on with different nutrition tools. Based on the scientific findings feed additives which have direct or indirect antioxidant effects can be used in general: Vitamin C, A, E alone or with other micro minerals, for example chrome and/or zinc (Horváth et al. 2016c).

The demand for poultry meat is increasing; the importance of duck meat is rising, although there is not much relevant data about their nutrition. Hungary is leading in production and costuming, the duck production is about 4.3 million, which is increasing by $30 \%$ each year. Successful and economic production is possible with intensive nutrition and concentrated nutrient content beside a temperature being equal to the animal's thermoneutral zone (Cherry and Morris 2008.). The thermoneutral zone of ducklings are $26.5-29.5^{\circ} \mathrm{C}$, but their temperature range decrease $3{ }^{\circ} \mathrm{C}$ weekly, reaching $18-20^{\circ} \mathrm{C}$ at the end of the growing period (FASS 2010).

Free radicals are formed due to heat stress, which is part of the general protection mechanism. The antioxidantprooxidant balance can be damaged in chronic phase, shifted to the prooxidant processes. The recovery is done by the so-called Three Level Antioxidant System. The first is the direct enzymatic pathway, free radicals are neutralized by enzymes e.g. Superoxide-dismutase enzyme (SOD). The second is the small molecule antioxidant group, which compounds are participated in detoxification and regeneration reactions. One of the most important antioxidant is Vitamin C. Vitamin E also plays an important role with strong antioxidant quality. The third level is activated when damaged proteins have to be repaired and/or removed from the cells. Damaged protein amount is increasing due to heat stress and heat shock protein synthesis begins. The most known heat stress protein is heat shock protein 70 (HsP70) which 
is located in the cytoplasm. (Horváth et al. 2016b). The antioxidant defence system plays an important role in the reduction of the heat stress generated lipid peroxidation process. Many studies prove that under short or long term heat stress the antioxidant system of broilers is damaged (Yang et al. 2010, Akbarian et al. 2015). According to our previous study we found the same results in ducks under chronic heat stress (Horváth et al. 2016a).

There are very limited and inconsequence number of scientific results on the digestibility of nutrients, production parameters and chemical composition of meat under heat stress in ducks. Long term heat stress has proved negative effects on the digestibility of nutrients in broilers (Hai et al. 2000, Daghir 2009). In contrast with these data Sahin and Kucuk (2001) find higher digestibility of nutrients with Vitamin $\mathrm{C}$ and $\mathrm{E}$ supplementation in diet under chronic heat stress $\left(34^{\circ} \mathrm{C}\right)$. However Laganá et al. (2007) could not detect any negative effect on the digestibility of nutrients when the environmental temperature was inconstant $\left(25-32^{\circ} \mathrm{C}\right)$.

Production parameters are also affected by chronic heat. Feed additives with antioxidant effect can be used to improve the performance of ducks. Vitamin C and E supplement in diets reduced the deterioration of daily weight gain (dWG) and feed conversion ratio (FCR) (Sahin and Kucuk 2001, Attia et al. 2011, Horváth et al. 2016a). Scientific findings on the chemical composition of duck meat under heat stress are limited; most of the experiments were done under thermoneutral conditions (Galal et al. 2011, Heo et al. 2015).

In summary the literature findings it can be conclude that there are very limited relevant information and hardly enough systematic studies are available about the negative effects on the antioxidant status, energy turnover, digestibility of the nutrients, production parameters and chemical composition of meat under long term heat stress in meat type ducks.

Therefor the aim of the study is to determine the effect of vitamin $\mathrm{C}$ and $\mathrm{E}$ and mineral (Zn) supplement in the diet under permanently high environmental temperature $\left(30 \pm 1^{\circ} \mathrm{C}\right)$ on the digestibility of nutrients, performance and furthermore the chemical composition of duck meat in the growing period.

\section{MATERIALS AND METHODS}

The experimental procedures were approved by University of Debrecen Animal Care Committee (Debrecen, Hungary).

\section{Birds}

A total of four hundred mixed sex 14 days old Cherry Valley type hybrid ducks were used for the study. The ducklings were fed by same compound feed for 14 days, before the start of the experiment at the Tranzitker Company's farm. The ducklings at the age of 14 days were placed to the animal house. The experiment started at 14 days of age and lasted for 42 days. The feed and water were available ad libitum.

\section{Housing}

In the animal house 10 pens were placed. Ducks were weighted and equally distributed among two groups of five replicate $(3.30 \times 1.5 \mathrm{~m})$ consisted of 20 birds.
The floor pens were housed in environmentally controlled rooms. The average room temperature was maintained at $30 \pm 1{ }^{\circ} \mathrm{C}$ for 24 hours every day and the relative humidity was $65 \pm 5 \%$. The temperature was monitored twelve times daily at different locations of the animal house. The lighting schedule of 23L:1D (2 lux) was provided (Cherry and Morris 2008). Ducks were kept in floor pens covered with straw for beddings. This experiment was repeated once more in same circumstances $(2 \times 200$ ducks $=400$ ducks).

\section{Dietary treatments, composition of diets and calculated nutrient content}

Two experimental diets were formulated in the study. The experimental diets (Table 1) were prepared by making a control diet, which can be used in normal environmental temperature (near to thermoneutral zone) and experimental diet (supplemented with Vitamin C and $\mathrm{E}$ and zinc). The composition and calculated nutrient contents of diets can be seen is Table 1 .

Table 1.

Composition and calculated nutrient contents of control and high-oxidant diets

\begin{tabular}{lcc}
\hline \multicolumn{1}{c}{$\begin{array}{c}\text { Composition } \\
\text { Cor }\end{array}$} & \multicolumn{2}{c}{ Diets } \\
\cline { 2 - 3 } Corn & 25.0 & 35.03 \\
Wheat & 20.0 & 10.0 \\
Triticale & 25.52 & 20.0 \\
Ext. Soy meal (CP: 46\%) & 3.62 & 10.64 \\
Full fat soya & 5.0 & 5.0 \\
Ext. sunflower granulate & 13.47 & 10.24 \\
Wheat meal & 3.0 & 6.0 \\
Others & $4.39 *$ & $3.09 * *$ \\
\hline \multicolumn{2}{c}{ Calculated nutrient content } & \multicolumn{2}{c}{ Diets } \\
\cline { 2 - 3 }$\quad$ (100 g dry matter) & Control & Experiment \\
\hline AMEn poultry (MJ per kg) & 12.3 & 12.0 \\
C. protein (\%) & 18.4 & 19.8 \\
C. fiber (\%) & 5.0 & 5.0 \\
Lysine (\%) & 1.0 & 1.1 \\
Methionine (\%) & 0.50 & 0.52 \\
Ca (\%) & 0.65 & 0.68 \\
Vitamin A (IU) & 10000 & 10000 \\
Vitamin D3 (IU) & 4000 & 4000 \\
Vitamin E (mg per kg) & 40 & 190 \\
Vitamin C (mg per kg) & 25 & 200 \\
Se (mg per kg) & 0.4 & 0.4 \\
Zn (mg per kg) & 100 & 110 \\
\hline & \multicolumn{2}{c}{ * Amiment } \\
\hline
\end{tabular}

Note: *Amino Acid supplementation: L-Lysine HCl, DL-Methionine, L-Threonine; Sunflower oil; Limestone; $\mathrm{MCP}$; Salt; $\mathrm{NaHCO}_{3}$; premix.

** Amino acid supplementation: L-Lysine $\mathrm{HCl}$, DL-Methionine, L-Threonine; Limestone; $\mathrm{MCP}$; Salt; $\mathrm{NaHCO}_{3}$; premix

\section{Measurements}

\section{Digestibility trial}

One duck from each pen was randomly euthanized by cervical dislocation at day 42 . Digesta was collected from the distal duodenum to the ileocecal junction (the entire ileum) according to Jin et al. (2000). The samples were placed in plastic holders and stored on $-20{ }^{\circ} \mathrm{C}$ until laboratory analysis $(n=20)$. 


\section{Performance trial}

The live weight (LW) of the ducks was measured at day 14 and 42 . The dWG was calculated individually. The daily feed intake (FI) was also recorded by each pen. The FCR and the energy and protein conversion was also calculated $(n=200)$.

\section{Meat analysis}

One duck from each pen was randomly euthanized by cervical dislocation at day 42 . The skinny leg and breast meat of the ducks was collected individually in plastic bags. The samples were stored on $-20{ }^{\circ} \mathrm{C}$ until laboratory analysis $(n=20)$.

\section{Chemical Analysis}

Diet

The nutrient and mineral content of the feed was determinated using standard procedures of Proximate Analysis (AOAC 2016). The diet samples were analysed for dry matter $(\mathrm{DM})$, nitrogen $(\mathrm{N})$, crude fat $(\mathrm{CF})$, crude fiber and ash. Dry matter of diets was determined by oven-drying $4 \mathrm{~h}$ at $103{ }^{\circ} \mathrm{C}$ ( MSZ ISO 6496:2001) and ash by complete combustion $\left(550{ }^{\circ} \mathrm{C}\right.$ for $24 \mathrm{~h}$ ) (MSZ ISO 5984:1992). Nitrogen content was determined by Kjeldahl method (MSZ EN ISO 5983:1:2005). Crude lipids were measured by Soxtec extract (TECATORSoxtec 1998).

\section{Digestibility}

The digestibility of nutrients in the small intestine was determined by post mortem digestibility trial using $\mathrm{SiO}_{2}$ as indicator (5 ducks/treatment). The digesta samples were analysed using standard procedures of Proximate Analysis (AOAC 2016). The following measurements were done: DM, CP, CF content of the digesta. The following formula was used to calculate the apparent digestibility of nutrients (Elbers et al. 1989):

$$
\mathrm{K}_{1}=100-100 \times \frac{\mathrm{I}_{\mathrm{F}}}{\mathrm{I}_{\mathrm{D}} \times \mathrm{F}} \times \frac{\mathrm{N}_{\mathrm{D}}}{\mathrm{N}_{\mathrm{F}}}
$$

where: $\mathrm{K}_{1}=$ either nutrient apparent digestibility (\%); $\mathrm{I}_{\mathrm{F}}=$ Indicator in Feed (\%); $\mathrm{N}_{\mathrm{D}}=$ Nutrient content of Digesta $(\%) ; \mathrm{I}_{\mathrm{D}}=$ Indicator in Digesta $(\%) ; \mathrm{N}_{\mathrm{F}}=$ Nutrient content of Feed (\%); F = Indicator Recovery Factor.
Meat

The meat samples were analysed for DM, protein, fat and ash using standard procedures of Proximate Analysis (AOAC 2016).

\section{Statistical Analysis}

The experimental data were analysed by General Lineal Modell of SAS (version 9.3; SAS Inst. Inc., Cary, NC) using the following general model:

$$
Y_{j j k}=\mu+t_{i}+r_{j}+(t \times r)_{i j}+e_{i j k}
$$

where: $\mathrm{Y}-$ Dependent variable; $\mu$ - Overall mean; $\mathrm{t}-$ Treatment $(\mathrm{i}=2) ; \mathrm{r}-$ Repeat $(\mathrm{j}=2) ; \mathrm{k} \times \mathrm{i}$ - Interaction between treatment and repeat; e - Residual error.

Tukey's multiple comparison test was conducted at a significance level of $\mathrm{P}<0.05$ (SAS 9.3.) Repeat and treatment repeat interactions were ignored, because these effects for trait were found non-significant.

\section{RESULTS}

\section{Digestibility of nutrients}

The digestibility coefficients are summarized in Table 2. As it can be seen the nutrient digestibility of ducks was not affected by the raised vitamin and mineral supplementation under long term heat stress. The digestibility of DM, CP and CF did not change significantly $(\mathrm{P}>0.05)$.

Table 2

Effect of antioxidant supplement on nutrient digestibility of

\begin{tabular}{|c|c|c|c|}
\hline \multirow{2}{*}{$\begin{array}{c}\text { Nutrient } \\
\text { digestibility }(\%)\end{array}$} & \multicolumn{2}{|c|}{ Treatments } & \multirow{2}{*}{ RMSE** } \\
\hline & Control group* & Treated group* & \\
\hline Dry matter & 78.5 & 80.3 & 1.8 \\
\hline Crude protein & 74.2 & 75.8 & 2.7 \\
\hline Crude fat & 35.7 & 37.6 & 20.4 \\
\hline
\end{tabular}
ducks under long term heat stress

Note: *Treatments are defined in section 2.3. **Root mean square error

\section{Growth performance}

In Table 3 the effect of antioxidant supplementation on the performance of ducks can be seen. In the treated group (diet supplemented with vitamin $\mathrm{C}$ and $\mathrm{E}$ and with zinc) the dWG increased and the FCR improved significantly $(\mathrm{P}<0.05)$. The energy and protein conversion was decreased also significantly $(\mathrm{P}<0.05)$.

\begin{tabular}{|c|c|c|c|}
\hline \multirow{2}{*}{ Items } & \multicolumn{2}{|c|}{ Treatments } & \multirow{2}{*}{ RMSE** } \\
\hline & Control group* & Treated group* & \\
\hline Daily Weight Gain (g per bird) & $44^{\mathrm{a}}$ & $53^{\mathrm{b}}$ & 9 \\
\hline Feed intake (kg per pen per 28 days) & $63^{\mathrm{a}}$ & $69^{\mathrm{b}}$ & 3.5 \\
\hline Feed intake (calculated) (g per bird per 28 days) & 3150 & 3450 & - \\
\hline Feed Conversion Ratio (kg per kg WG) & $2.7^{\mathrm{a}}$ & $2.2^{\mathrm{b}}$ & 0.2 \\
\hline Energy Conversion Ratio (MJ AMEn per kg WG) & $333.2^{\mathrm{a}}$ & $267.6^{\mathrm{b}}$ & 27.8 \\
\hline Protein Conversion Ratio (g protein per kg WG) & $443^{\mathrm{a}}$ & $393^{\mathrm{b}}$ & 42 \\
\hline
\end{tabular}

Effect of antioxidant supplement on performance of ducks under long term heat stress $(n=200)$

Note: *Treatments are defined in section $2.3 . * *$ Root mean square error. a,b Different superscripts in the same row indicate significant differences between groups at $\mathrm{P}<0.05$ level. 


\section{Meat chemical composition}

As it can be seen in Table 4 the DM and ash content was not affected by the higher vitamin $\mathrm{C}$ and $\mathrm{E}$ and zinc content of diet under heat stress. The protein content was higher in the treated group but not significantly $(\mathrm{P}>0.05)$. Fat decreased in the treated group but also not significantly $(\mathrm{P}>0.05)$.

Table 4

Effect of antioxidant supplement on leg meat composition of ducks under long term heat stress

\begin{tabular}{lccc}
\hline \multirow{2}{*}{\begin{tabular}{c} 
Meat composition $($ leg) $(\%)$ \\
\cline { 2 - 3 }
\end{tabular}} & \multicolumn{2}{c}{ Treatments } & \\
\hline Dry matter & 23.8 & 23.5 & 0.8 \\
Protein & 19.9 & 20.3 & 2.5 \\
Fat & 2.5 & 1.9 & 2.6 \\
Ash & 1.1 & 1.1 & 0.4 \\
\hline
\end{tabular}

Note: *Treatments are defined in section 2.3.**Root mean square error.

The breast meat was also analysed to examine the difference in the chemical composition between the control and treated group. Table 5 shows a similar tendency to the results of the leg meat. The DM and ash was not affected by the supplementation under heat stress. The protein content increased but not significantly $(\mathrm{P}>0.05)$. Fat decreased but not significantly in treated group $(\mathrm{P}>0.05)$.

Table 5 .

Effect of antioxidant supplement on breast meat composition of ducks under long term heat stress

\begin{tabular}{lccc}
\hline \multirow{2}{*}{$\begin{array}{c}\text { Meat composition } \\
\text { (breast) (\%) }\end{array}$} & \multicolumn{2}{c}{ Treatments } & \\
\cline { 2 - 3 } & Control group* & Treated group* & \\
\hline Dry matter & 23.5 & 23.4 & 0.8 \\
Protein & 21.3 & 21.5 & 0.8 \\
Fat & 0.6 & 0.5 & 0.5 \\
Ash & 1.3 & 1.3 & 0.6 \\
\hline
\end{tabular}

Note: $*$ Treatments are defined in section $2.3 . * *$ Root mean square error.

\section{DISCUSSION}

Based on different experiments carried out under heat stress it was found that heat stress has negative effects on nutrient digestibility (Hai et al. 2000, Daghir 2009). However, it should be noticed that there are limited and inconsequence number of scientific results on the digestibility of nutrients in ducks under heat stress. Digestibility of DM under heat stress in broilers can be very various: from $66 \%$ (Bonett et al. 1997) to $73 \%$ (Seven and Seven 2011). Our results show that digestibility of DM in control $(78.5 \%)$ and treatment $(80.3 \%)$ group are both higher than in the literature. The digestibility of crude protein is range from $67 \%$ (Bonnett et al. 1997, Seven and Seven 2011) to 80-84\% (Hosseini and Afsar 2016) in the literature. In general Vitamin $C$ addition under heat stress improves the digestibility of nutrients although in our study it was not expressive. In our study the digestibility of $\mathrm{CP}$ is ranged between the results of Seven and Seven (2011) and Hosseini and Afsar (2016) in both treatments. Digestibility of crude protein was not affected by supplementation. In general it can be said that the digestibility values are appropriate for the digestibility of ducks (Seven and Seven 2011).

Feed additives which have direct or indirect antioxidant effect can be used to protect the animals against the negative effects of heat stress. Vitamin $\mathrm{C}$ has improved the performance under heat stress in broilers (Attia et al. 2011). Vitamin $C$ and $E$ used together also increased the dWG and the FCR under heat stress in broilers (Sahin and Kucuk 2001). Zinc is a necessary element for growth and development and also for immuncompetance. It also plays a role in carbohydrate and energy metabolism; protein synthesis and catabolism. Under heat stress these systems are damaged, but with zinc supplementation the negative effects can be reduced (Kucuk et al. 2003). In our study we used two treatments. The control group was fed with a diet required to nutrient content in the thermoneutral zone. The experimental group was fed with diet supplemented with vitamin (Vitamin $\mathrm{C}$ and E) and mineral (zinc). The results showed same effects as the scientific papers: the production parameters were affected by higher vitamin and mineral supplementation under heat stress. In the treated group the dWG increased and the FCR improved significantly $(\mathrm{P}<0.05)$. The energy and protein conversion was decreased also significantly $(\mathrm{P}<0.05)$.

The chemical composition of duck breast in different experiments determined as $20-21 \%$ protein, $1.5-3.6 \%$ fat and $0.9-1.8 \%$ ash content under thermoneutral conditions and without supplementation (Galal et al. 2011, Heo et al. 2015). Aksit el al. (2006) and Tankson et al. (2001) reported that heat treatment caused reductions in protein content of the carcass. In our study the protein content of duck leg (19.9\%) and breast meat (21.3\%) decreased but not significantly without antioxidant supplementation under long term heat stress $(\mathrm{P}>0.05)$. We got the same results of protein content in the treated group as in the previously mentioned studies under normal environmental temperature (leg: $20.3 \%$; breast: $21.5 \%$ ). Our results show that in treated group the fat content was lower (leg: 1.9\%; breast: $0.5 \%$ ) than control group (leg: $2.5 \%$; breast: $0.5 \%$ ); antioxidant supplementation has improved the fat content of duck meat. Ash content did not change, although the feed was supplemented with high dose of vitamins and zinc. Higher dose of Vitamin (C, E) and mineral ( $\mathrm{Zn})$ supplementation under heat stress has improved effects on the chemical composition of duck meat, especially on protein and fat content.

\section{CONCLUSION}

Based on the results the following conclusions can be drown:

- The antioxidant defence system plays an important role in the reduction of heat stress generated lipid peroxidation process. Feed additives which have direct or indirect antioxidant effects can reduce the negative effects of heat stress on the ducks performance and meat composition.

- Digestibility of nutrients (DM, CP, CF) was not affected by antioxidant supplementation under chronic heat stress $\left(30 \pm 1{ }^{\circ} \mathrm{C}\right)$. 
- The performance of ducks was affected significantly by vitamin $\mathrm{C}$ and $\mathrm{E}$ and zinc supplementation under chronic heat stress. In the treated group the daily weight gain increased and the feed conversion ratio was improved significantly when the diet contains $190 \mathrm{mg} \mathrm{kg}^{-1}$ Vitamin E, $200 \mathrm{mg} \mathrm{kg}^{-1}$ Vitamin C and $110 \mathrm{mg} \mathrm{kg}^{-1}$ zinc. The energy and protein conversion was decreased also significantly.

\section{ACKNOWLEDGMENT}

This study was supported in part by Hungarian Research Fund (TÁMOP 4.2.2D-15/1). The authors gratefully acknowledge the generous sponsorship of Tranzitker Trading Company, Debrecen, Hungary (www.tranzitker.hu).

\section{IRODALOM}

Akbarian, A.-Golian, A.-Kermanshahi, H.-De Smet, S.-Michiels, J. (2015): Antioxidant enzyme activities, plasma hormone levels and serum metabolites of finishing broiler chickens reared under high ambient temperature and fed lemon and orange peel extracts and Curcuma xanthorrhiza essential oil. Journal of Animal Physiology and Animal Nutrition. 99. 1: 150-162.

Akşit, M.-Yalcin, S.-Özkan, S.-Metin, K.-Özdemir, D. (2006): Effects of temperature during rearing and crating on stress parameters and meat quality of broilers. Poultry Science. 85 . 11: $1867-1874$

Attia, Y. A.-Hassan, R. A.-Tag El-Din, A. E.-Abou-Shehema, B. M. (2011): Effect of ascorbic acid or increasing metabolizable energy level with or without supplementation of some essential amino acids on productive and physiological traits of slow-growing chicks exposed to chronic heat stress. Journal of Animal Physiology and Animal Nutrition. 95. 6: 744-755.

Babinszky, L.-Halas, V.-Verstegen, M. W. A. (2011): Impacts of climate change on animal production and quality of animal food products [In: Blanco, J. A.-Kheradmand, H. (eds.) Climate Change-Socioeconomic Effects.] Tech Open Access Publisher Rijeka. Croatia. 165-190.

Bonnet, S.-Geraert, P. A.-Lessire, M.-Carre, B.-Guillaumin, S. (1997): Effect of high ambient temperature on feed digestibility in broilers. Poultry Science. 76. 6: 857-863.

Cherry, P.-Morris, T. (2008): Domestic duck production: science and practice. $\mathrm{CABI}$

Daghir, N. J. (2009): Nutritional strategies to reduce heat stress in broilers and broiler breeders. Lohmann Inform. 44. 1: 6-15.

Elbers, A. R. W.-Den Hartog, L. A.-Verstegen, M. W. A.-Zandstra, T. (1989): Between-and within-herd variation in the digestibility of feed for growing-finishing pigs. Livestock Production Science. 23. 1: $183-193$.

FASS (Federation of Animal Science Societies) (2010): Guide for the care and use of agricultural animals in research and teaching. Champaign. Illinois. USA. 116-117.

Galal, A.-Ali, W. A. H.-Ahmed, A. M. H.-Ali, K. A. (2011) Performance and carcass characteristics of Dumyati, Muscovy, Peking and Sudani duck breeds. Egyptian Journal of Animal Production. 48. 2: 191-202.

Hai, L.-Rong, D.-Zhang, Z. Y. (2000): The effect of thermal environment on the digestion of broilers. Journal of Animal Physiology and Animal Nutrition. 83: 57-64.

Heo, K. N.-Hong, E. C.-Kim, C. D.-Kim, H. K.-Lee, M. J.-Choo, H. J.-Kim, J. H. (2015): Growth performance, carcass yield, and quality and chemical traits of meat from commercial Korean native ducks with 2-way crossbreeding. Asian-Australasian Journal of Animal Sciences. 28. 3: 382-390.
Horváth M.-Asbóth G.-Gálné Remenyik J.-Babinszky L. (2016a): A tartós hö-stress káros hatásának csökkentése takarmányozási módszerekkel a pecsenyekacsa tartásban. [In: Szalka É.-Bali Papp Á. (szerk.) XXXVI. Óvári Tudományos Nap: Hagyomány és innováció az agrár- és élelmiszergazdaságban.] Mosonmagyaróvár, 2016. november. 10. Széchenyi István Egyetem Mezögazdaság- és Élelmiszertudományi Kar. 407-412.

Horváth M.-Asbóth G.-Gálné Remenyik J.-Babinszky L. (2016b): A hőstressz káros hatása a brojler antioxidáns státuszára és ezen hatás csökkentése takarmányozással - II. rész. A hőstressz csökkentése takarmányozási módszerekkel. Magyar Állatorvosok Lapja. 138. 9: 559-564.

Horváth M.-Asbóth G.-Gálné Remenyik J.-Babinszky L. (2016c): A hőstressz káros hatása a brojler antioxidáns státuszára és ezen hatás csökkentése takarmányozással - I. rész. A hőstressz és az antioxidáns védelmi rendszer. Magyar Állatorvosok Lapja. 138. 8: $471-481$

Hosseini, S. M.-Afshar, M. (2016): Effects of feed form and xylanase supplementation on performance and ileal nutrients digestibility of heat-stressed broilers fed wheat-soybean diet. Journal of Applied Animal Research. 45. 1: 550-556.

Jin, L. Z.-Ho, Y. W.-Abdullah, N.-Jalaludin, S. (2000): Digestive and bacterial enzyme activities in broilers fed diets supplemented with Lactobacillus cultures. Poultry Science. 79. 6: 886-891.

Kucuk, O.-Sahin, N.-Sahin, K. (2003): Supplemental zinc and vitamin A can alleviate negative effects of heat stress in broiler chickens. Biological Trace Element Research. 94. 3: 225-235.

Laganá, C.-Ribeiro, A. M. L.-Kessler, A. M.-Kratz, L. R.-Pinheiro, C. C. (2007): Effects of the reduction of dietary heat increment on the performance, carcass yield, and diet digestibility of broilers submitted to heat stress. Revista Brasileira de Ciência Avícola. 9. 1: 45-51.

Sahin, K.-Kucuk, O. (2001): Effects of vitamin C and vitamin E on performance, digestion of nutrients and carcass characteristics of Japanese quails reared under chronic heat stress (34 C). Journal of Animal Physiology and Animal Nutrition. 85. 11-12: 335-341.

Seven, P. T.-Seven, I. (2008): Effect of dietary Turkish propolis as alternative to antibiotic on performance and digestibility in broilers exposed to heat stress. Journal of Applied Animal Research. 34. 2: 193-196.

Tankson, J. D.-Vizzier-Thaxton, Y.-Thaxton, J. P.-May, J. D.Cameron, J. A. (2001): Stress and nutritional quality of broilers. Poultry Science. 80. 9: 1384-1389.

Yang, L.-Tan, G. Y.-Fu, Y. Q.-Feng, J. H.-Zhang, M. H. (2010): Effects of acute heat stress and subsequent stress removal on function of hepatic mitochondrial respiration, ROS production and lipid peroxidation in broiler chickens. Comparative Biochemistry and Physiology Part C: Toxicology \& Pharmacology. 151.2: 204-208. 
